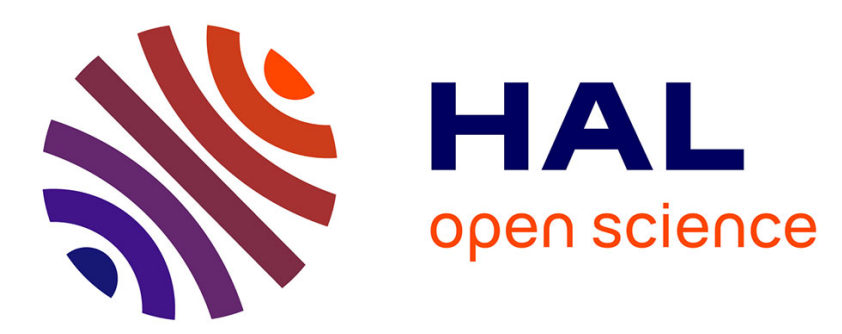

\title{
Gold particles growth on carbon felt for efficient micropower generation in a hybrid biofuel cell
}

Thi Xuan Huong Le, Mikhael Bechelany, Adriana Both Engel, Marc Cretin, Sophie Tingry

\section{- To cite this version:}

Thi Xuan Huong Le, Mikhael Bechelany, Adriana Both Engel, Marc Cretin, Sophie Tingry. Gold particles growth on carbon felt for efficient micropower generation in a hybrid biofuel cell. Electrochimica Acta, 2016, 219, pp.121 - 129. 10.1016/j.electacta.2016.09.135 . hal-01688067

\section{HAL Id: hal-01688067 \\ https://hal.umontpellier.fr/hal-01688067}

Submitted on 7 Jul 2021

HAL is a multi-disciplinary open access archive for the deposit and dissemination of scientific research documents, whether they are published or not. The documents may come from teaching and research institutions in France or abroad, or from public or private research centers.
L'archive ouverte pluridisciplinaire HAL, est destinée au dépôt et à la diffusion de documents scientifiques de niveau recherche, publiés ou non, émanant des établissements d'enseignement et de recherche français ou étrangers, des laboratoires publics ou privés. 


\section{Gold particles growth on carbon felt for efficient micropower generation in a hybrid biofuel cell}

Thi Xuan Huong Le ${ }^{\mathrm{a}, \mathrm{b}}$, Mikhael Bechelany ${ }^{\mathrm{a}}$, Adriana Both Engel ${ }^{\mathrm{a}}$, Marc Cretin ${ }^{\mathrm{a}}$, Sophie Tingry ${ }^{\mathrm{a}}$

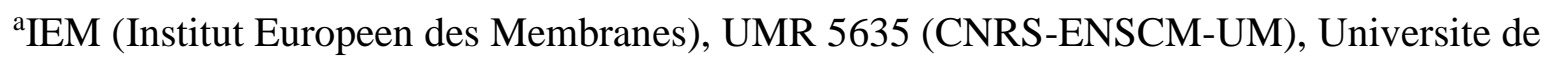

Montpellier, Place E. Bataillon, F- 34095, Montpellier, France.

${ }^{\text {b}}$ Van Lang University, 45 Nguyen Khac Nhu, District 1, Ho Chi Minh City, Viet Nam.

Corresponding author Email: $\underline{\text { sophie.tingry@umontpellier.fr }}$

\section{ABSTRACT}

In this study, homogeneously dispersed gold particles growth onto carbon felt were fabricated by electrodeposition method followed by a thermal treatment at $1000{ }^{\circ} \mathrm{C}$ under nitrogen. The thermal treatment induced the dewetting of gold and the formation of well-crystallized gold particles that exhibited large surface area. The structural properties of the resulted Au@CF material were evaluated by SEM, XRD and TGA. We studied the electrocatalytic properties of this new gold material through the abiotic glucose oxidation in alkaline medium and the enzymatic dioxygen electroreduction by the enzyme bilirubin oxidase. Finally, we showed the potentiality of the resultingAu@CF material to build a 3-dimensional glucose hybrid biofuel cell by assemblying an abiotic anode with an enzymatic cathode. The system exhibited high electrochemical performance with an open circuit voltage of $0.71 \mathrm{~V}$ and a maximum power density of $310 \mu \mathrm{W} \mathrm{cm}$

${ }^{2}$ at $352 \mathrm{mV}$ (by taking into account the projected surface area), in spite of a low gold loading ( 0.2 $\mathrm{wt} \%$ ). The advance presented in this work is the efficiency of the synthesis technique to get a new 
free-standing material for electrocatalysis based on gold particles with high reactive surface area for electron transfer and macropores for diffusion transport.

Keywords: gold particles, electrodeposition, dewetting, glucose, enzyme, hybrid biofuel cell.

\section{Introduction}

Gold nanoparticles (AuNPs) and nanoporous gold, as well as metallic nanostructured films are becoming popular as electrode materials for electrocatalysis. These electrodes are attractive due to their large electrochemical surface area, excellent chemical stability, high conductivity and biocompatibility $[1,2]$. Several techniques are used to prepare three-dimensional gold electrodes mainly based on (i) the immobilization of already synthesized nanoparticles by drop-casting, layer-by-layer methods and entrapment in a sol gel matrix [3-8], or (ii) the direct preparation of nanoparticles on electrode surface by electrochemical deposition, sputtering followed by dealloying, chemical reduction, seed-mediated growth and ion implantation [9-13]. These techniques use high metal loading (20-40 wt.\%) [3], and since gold is an expensive material, they are mostly adapted for small electrode areas, and require strong reducing agents (boron hydride) and thiol groups for nanoparticles stabilization $[7,8]$.

Thanks to their catalytic efficiency and biocompatibility, AuNPs can be used either coimmobilized with redox enzymes or as the main catalyst. Three-dimensional gold nanoparticles electrodes have been widely applied to direct electron transfer reactions of redox enzymes [14-19], which can afford higher enzyme loading, better orientation by chemical modification and more efficient electrical contact. From examples found in the literature, AuNPs electrodes have shown to improve biofuel cells performance $[20,21]$ and glucose biosensors detection $[17,22]$ compared to planar electrodes. Additionally, AuNPs exhibit good activity toward glucose oxidation (with typical current values ranging from some hundreds of $\mu \mathrm{A}$ to a few $\mathrm{mA}$ ) due to their large surface 
area, high number of active sites and resistance to surface poisoning during electrochemical processes $[7,23,24]$.

Hybrid biofuel cells, unlike fully enzymatic ones, present only one enzymatic electrode (bioanode or biocathode), while the other is catalyzed by nanometallic catalysts. In enzymatic BFCs, the enzymes offer high reactant specificity and high reaction rate. Glucose oxidase has been widely studied in glucose biofuel cells through MET-type catalysis (Mediated Electron Transfer) with the use of mediators such as ferrocene [25] or osmium complexes [26, 27] or through DETtype catalysis (Direct Electron Transfer) with the introduction of nanomaterials including carbon nanotubes, graphene or gold NPs [19]. However, the limited stability and regeneration of the enzymes hinder the potential use of enzymatic glucose BFC for long-term operation. An alternative option is thus the use of abiotic catalysts with high catalytic activity toward glucose oxidation and efficient stability that makes them more suitable for long-term applications. The non-selectivity of abiotic glucose catalysts can be easily overcome by the addition of a separation membrane. In our previous studies, we reported the construction of hybrid biofuel cells involving an abiotic anode and an enzymatic cathode that can potentially convert chemical energy into electricity [28, 29]. The devices were made of self-standing electrospun carbon electrodes modified by Au NPs at the anode for the electrocatalytic oxidation of glucose and by the enzyme bilirubin oxidase (BOD) at the cathode for the electrocatalytic reduction of dioxygen. The abiotic anodes were obtained either by the direct synthesis of the nanoparticles supported on carbon Vulcan ${ }^{\circledR}$ and deposited on the electrode surface [28], or by the formation in situ of the nanoparticles embedded in electrospun carbon fibers [29]. The electrodes were characterized by gold loadings of 21 and $12.2 \mathrm{wt} \%$, respectively, determined by thermogravimetric analysis. These results clearly showed the advantage to preparein situ the nanoparticles to form very stable carbon-gold bonding with well dispersed AuNPs on the electrode surface to enhance the long-term stability of our devices.

Considering the importance of the bonding stability between the NPs and the electrode material, the aim of this work is to propose a new simple method to prepare gold particles attached 
on a commercial porous carbon template that affords conformal coating and homogeneous dispersion of the gold onto the electrode surface. The technique is applied to prepare $\mathrm{Au} @ \mathrm{CF}$ material with the objective of using a very low gold loading $(0.2 \mathrm{wt} \%)$. Besides, compared to our previous studies, the bioelectrode is prepared by connecting AuNPs directly to the enzymes instead of using MWCNTs to establish electrical contact. The Au@CF material is obtained from the electrodeposition of gold salts on a porous carbon felt followed by a subsequent thermal treatment at $1000^{\circ} \mathrm{C}$ under nitrogen gas flow to induce the dewetting of gold [30], and the formation of well-crystallized gold particles that exhibit large surface area. The benefits of this synthetic route is achieving a free-standing material with (i) increased reactive surface area induced by the Au nanoparticles for high enzyme loadings, and (ii) high mass transport of reactants thanks to the porous carbon template.

To our knowledge, this is the first time that this synthesis approach is used to confine gold particles in a three-dimensional electrode applied to the development of hybrid biofuel cells. Structural properties of the new Au@CF material are characterized by scanning electron microscopy (SEM), energy dispersive X-ray spectroscopy (EDX), and thermogravimetric analysis (TGA). We focus on the electrocatalyic properties of this new material regarding both the abiotic glucose oxidation in alkaline medium and the enzymatic dioxygen electroreduction. The enzyme $\mathrm{BOD}$, known to promote the four-electron reduction of oxygen directly to water [31], was chosen to perform DET. DET allows avoiding the problems associated with the use of redox mediators like limited stability, potential toxicity and lower electrode potential. As DET depends significantly on the distance between the redox active center of the enzyme and the electrode surface, we expect that the gold nanoparticles will promote DET between the BOD and the porous carbon electrode. BOD is entrapped within chitosan matrix which provides favorable microenvironment and high stability for multicopper oxidases [32], and further immobilized within the porous Au@CF by simple immersion in solutions. Finally, the potentiality of the resulting Au@CF electrodes to assemble a glucose hybrid biofuel cell is shown by using bare CF@Au at the anode, and BOD-modified CF@Au at the cathode. In spite of low gold loading (0.2 
$w t \%)$, this hybrid device exhibits higher electrochemical performance than the previous hybrid glucose biofuel cells, proving the efficiency of the synthesis technique to form gold electrodes with high active surface for electrocatalysis.

\section{Experimental}

\subsection{Materials}

The carbon felt was purchased from A Johnson Matthey Co., Germany. Chloroauric acid trihydrate $\left(\mathrm{HAuCl}_{4} \cdot 3 \mathrm{H}_{2} \mathrm{O}, 99.99 \%\right)$ was obtained from Sigma Aldrich. Potassium hexacyanoferrate $(\geq 99 \%)$ and potassium nitrate $(\geq 99 \%)$ were bought from Fluka, enzyme bilirubin oxidase (BOD, $2.51 \mathrm{U} \mathrm{mg}^{-1}$ solid) from Amano Enzyme Inc., Japan; potassium hydroxide (KOH pellets pure) from Merck; D-(+)-glucose monohydrate, chitosan and acid sulfuric (98\%) from Sigma-Aldrich, and used without further purification. Dihydrogen phosphate monohydrate $\left(\mathrm{NaH}_{2} \mathrm{PO}_{4} \cdot \mathrm{H}_{2} \mathrm{O}\right)$ and di-sodium hydrogen phosphate $\left(\mathrm{Na}_{2} \mathrm{HPO}_{4}\right)$ salts from Merck were employed for preparation of the buffer phosphate $(0.1 \mathrm{M}) \mathrm{pH} 7.0$ (PBS). The aqueous solutions were prepared using 18.2 $\mathrm{M} \Omega \mathrm{cm}$ MilliQ water (Millipore). Glucose solution was stirred for $24 \mathrm{~h}$ prior to use.

\subsection{Preparation of gold nanoparticles-modified carbon felt (CF@Au)}

The commercial carbon felt was firstly cleaned in an ultrasonic bath with acetone for $2 \mathrm{~h}$ to remove adsorbed contaminations, followed by thorough rinse with deionized water and drying at $60{ }^{0} \mathrm{C}$ for 24h. This pretreated carbon felt was denoted as raw CF. After that, the gold layer was deposited on the surface of the porous carbon by cyclic voltammetry (CV) technique running 70 scans from 0.9 to $0 \mathrm{~V}$ versus SCE (Saturated Calomel Electrode) at a scan rate of $10 \mathrm{mV} \mathrm{s}^{-1}$ in a $\mathrm{N}_{2}$-saturated solution containing $0.05 \mathrm{mg} \mathrm{mL}^{-1}$ chloroauric acid. The process was recorded on a $\mu 3 \mathrm{AUT} 70466$ Autolab system (Eco Chemie BV, Netherlands) at a scan rate of $10 \mathrm{mV} \mathrm{s}^{-1}$ using a three-electrode system with the $\mathrm{CF}$ as working electrode, a SCE as reference electrode and platinum foil as counter electrode. Aiming to form the gold particles by dewetting, an additional thermal treatment 
was realized in a tubular furnace (Vecstar Ltd) fed by nitrogen gas at the flow rate of $200 \mathrm{~mL} \mathrm{~min}{ }^{-1}$ with heating rate of $5{ }^{0} \mathrm{C} \mathrm{min}-1$ and temperature ranging from 20 to $1200{ }^{0} \mathrm{C}$. The parameters affecting the deposition of gold nanoparticles on the surface of the carbon felt were investigated, such as the concentration of chloroauric acid and treatment temperature. One electrode was prepared for each chloroauric acid trihydrate concentrations and for each treatment temperature from 600 to $1000{ }^{\circ} \mathrm{C}$. The sample at the best state was noted as gold carbon felt (CF@Au).

\subsection{Preparation of enzyme-immobilized electrode}

The biocathode consisted of an Au@CF electrode modified with BOD enzyme entrapped in a chitosan film. First the Au@CF material was immersed in a solution $(300 \mu \mathrm{L})$ of BOD $(19.5 \mathrm{mg}$ $\left.\mathrm{mL}^{-1}\right)$ in PBS $(0.1 \mathrm{M}) \mathrm{pH} 7$ until complete absorption of the liquid inside the porous electrode. More concentrated solutions of BOD did not yield higher catalytic currents. After drying, the modified electrode was covered by a chitosan solution, also by immersion. The solution was prepared by dissolving $1 \mathrm{wt} . \%$ of chitosan in $1 \mathrm{~mL}$ of acetic acid solution ( 1 vol.\%) until complete dissolution, followed by the addition of $50 \mu \mathrm{L}$ glutaraldehyde. The resulting electrode was let to dry at $5^{\circ} \mathrm{C}$ for $48 \mathrm{~h}$. The enzyme concentration was estimated at $5.8 \mathrm{mg}$ for a projected surface area of $1 \mathrm{~cm}^{2}$ for an electrode of $1 \mathrm{~cm}$ thickness.

\subsection{Material characterization}

Chemical and structural characterizations were performed by scanning electron microscopy (SEM, Hitachi S-4800), Thermogravimetric Analysis (TGA) using a TA instruments SDT 2960 under air atmosphere in the temperature range $25-800^{\circ} \mathrm{C}$, and by $\mathrm{X}$-ray diffraction (XRD) (PANAlytical Xpert-PRO diffractometer equipped with a X'celerator detector using Ni-filtered Cu-radiation).

\subsection{Electrochemical characterizations}


Cyclic voltammograms (CVs) experiments were conducted in a solution of $10 \mathrm{mM}$ $\mathrm{K}_{3}\left[\mathrm{Fe}(\mathrm{CN})_{6}\right]$ in $1.0 \mathrm{M} \mathrm{KNO}_{3}$ by using a $\mu 3 \mathrm{AUT70466}$ Autolab system (Eco Chemie BV, Netherlands) and a three-electrode cell with $\mathrm{Au} @ \mathrm{CF}$ or $\mathrm{CF}$ as working electrode, Pt foil as counter electrode, and a SCE as reference.

The Au@CF electrode (projected surface area of $1 \mathrm{~cm}^{2}$ for an electrode of $1 \mathrm{~cm}$ thickness) was analyzed for various chloroauric acid trihydrate concentrations by recording cyclic voltammograms in a $0.5 \mathrm{M} \mathrm{H}_{2} \mathrm{SO}_{4}$ solution at a scan rate of $10 \mathrm{mV} \mathrm{s}^{-1}$. The electrochemically active surface area (EASA) of the electrode provided by the particles was calculated from the experimental charge required to strip by reduction the $\mathrm{Au}$ oxide layer at $0.9 \mathrm{~V}$ vs $\mathrm{Ag} / \mathrm{AgCl}$ by using the theoretical charge density of $390 \mu \mathrm{C} \mathrm{cm}^{-2}$ associated with the reduction of gold oxide [33].

Glucose electrooxidation was investigated with $\mathrm{Au} @ \mathrm{CF}$ and raw $\mathrm{CF}$ electrodes by cyclic voltammetry in $0.1 \mathrm{M} \mathrm{KOH}$ containing $10 \mathrm{mM}$ glucose. Dioxygen reduction was performed by linear scan voltammetry measurements at scan rate of $3 \mathrm{mV} \mathrm{s}^{-1}$ in dioxygen-saturated phosphate buffer (pH 7.0,0.1 M) after stabilization of the BOD-modified Au@CF open circuit potential. The current density was normalized by the projected surface area of the electrodes, i.e. the geometrical area of the base of a parallelepiped rectangle.

For hybrid biofuel cell tests, the electrochemical performance was evaluated by the constant resistance discharge (CRD) technique with a variable external resistance applied to the cell, ranging from $10 \mathrm{M} \Omega$ to $100 \Omega$. The current and power were derived from the resistance and the cell voltage. The tests were performed in a two-chamber cell, with a Nafion ${ }^{\circledR} 117$ perfluorinated membrane $(3.5 \mathrm{~cm} \times 5 \mathrm{~cm})$ separating the anode and cathode compartments. The cathode compartment contained $25 \mathrm{~mL}$ PBS $(\mathrm{pH} 7.0,0.1 \mathrm{M})$ at $30{ }^{\circ} \mathrm{C}$ saturated with $\mathrm{O}_{2}$. The anode compartment consisted in $25 \mathrm{~mL}$ of glucose $(10 \mathrm{mM})$ in $0.1 \mathrm{M} \mathrm{KOH}(\mathrm{pH} \mathrm{11.0)}$. The size of the anode and cathode electrodes was similar and equivalent to $1 \mathrm{~cm}^{2}$ for an electrode of $1 \mathrm{~cm}$ thickness. The evolution of the anode and cathode potentials was monitored individually by inserting a reference electrode in each compartment of the two-chamber cell. Three gold particle- 
based electrodes were tested in the hybrid biofuel cell device and the electrochemical performance resulted from averages values.

\section{Results and discussion}

\subsection{Characterization of the structural properties of gold particles on carbon felt}
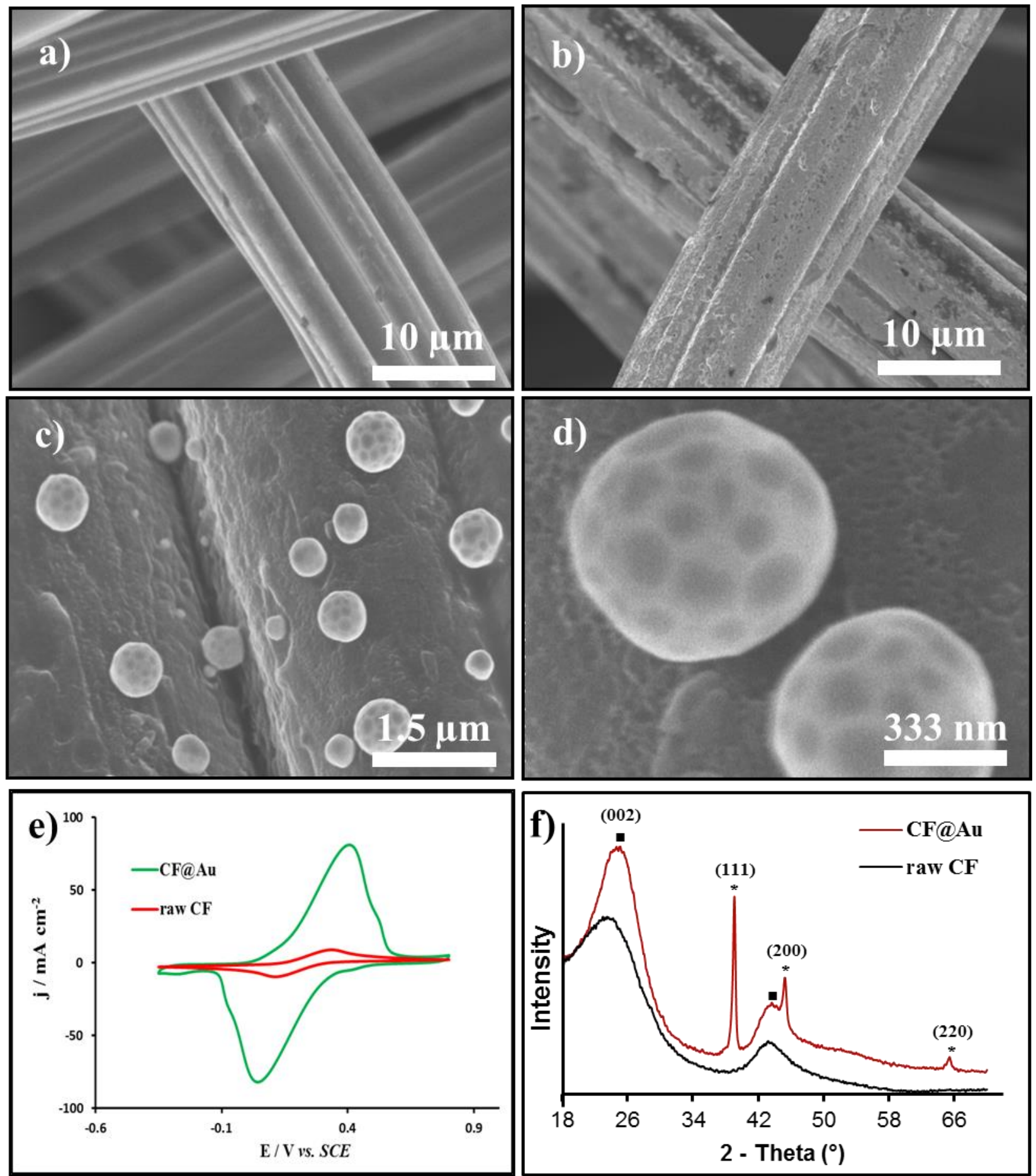

Figure 1. SEM images of (a) raw CF, (b) Au@CF without thermal treatment, (c, d) Au@CF after heating treatment at $1000^{\circ} \mathrm{C}$ for 1h, (e) Cyclic voltammograms of raw CF and Au@CF electrodes in potassium hexacyanoferrate solution 
(10 mM) PBS (pH 7) at scan rate $10 \mathrm{mV} \mathrm{s}^{-1}$, (f) X-ray diffraction patterns of raw CF and CF@Au. Au (*), C (- $)$.

Gold particles were deposited on a carbon felt by cyclic voltammetry from a solution of chloroauric acid trihydrate followed by a thermal treatment at $1000{ }^{\circ} \mathrm{C}$ under nitrogen gas for 1 hour. Regarding the SEM graphs in Figure 1a, it can be seen that the raw CF presents a smooth surface, while the surface morphology of $\mathrm{Au} @ \mathrm{CF}$ without thermal treatment is quite rough because of the envelopment of the carbon fibers by a thin gold layer (Figure 1b). After a thermal treatment at $1000{ }^{\circ} \mathrm{C}$, hexagon-shaped gold particles with an average size of $300 \mathrm{~nm}$ are formed by dewetting and are homogeneously distributed on the surface of the carbon felt (Figures 1c, d). From TGA analysis (Figure S1), the gold loading is $0.2 \%$ wt. in the Au@CF samples which corresponds to the gold amount in the initial solution of chloroauric acid trihydrate $\left(0.05 \mathrm{mg} \mathrm{mL}^{-}\right.$ $1)$.

The benefit of gold particles was illustrated by the cyclic voltammetry of the $\mathrm{Fe}(\mathrm{CN})_{6}^{3-/ 4-}$ redox probe, which shows a significant increase in current density on substituting raw CFs with $\mathrm{Au} @ \mathrm{CF}$ (Figure 1e). The presence of the three-dimensional gold particles notably improves the intensity of the peak current by 9 times showing an increase on the electrochemical activity The electrochemical impedance spectroscopy of $\mathrm{Au} @ \mathrm{CF}$ and raw $\mathrm{CF}$ electrodes in $10 \mathrm{mM}$ $\mathrm{K}_{3}\left[\mathrm{Fe}(\mathrm{CN})_{6}\right]$ in $\mathrm{KNO}_{3}$ solution was also performed (Figure S2). The interfacial charge-transfer resistance (Rct) is $0.15 \Omega$ for $\mathrm{Au} @ \mathrm{CF}$, compared to $2.3 \Omega$ for raw $\mathrm{CF}$, confirming that the presence of gold particles on the electrodes decreases the electrochemical resistance of the electrodes and accelerates the electron transfer efficiency.

The Au@CF material was characterized by XRD (Figure 1f). The broad diffraction peak at around $23^{\circ}$, defined for hexagonal graphite structures (002) and the smaller peak at $43^{\circ}$ are characteristic of the raw CF sample. Crystal gold on the surface of carbon felt is proved through the emergence of the sharp peaks at $38.2^{\circ}(111), 44.2^{\circ}(200)$ and $64.6^{\circ}(220)$, which are specific for cubic gold $[34,35]$. This analysis confirmed that gold particles were successfully obtained from the reduction of the chloroauric anions by electrodeposition that formed a gold layer on the 
carbon felt surface, subsequently transformed into particles by thermal treatment. The mechanism of formation of the gold particles by heat treatment will be discussed in details later in this manuscript.

\subsection{Effect of the gold loading quantity}

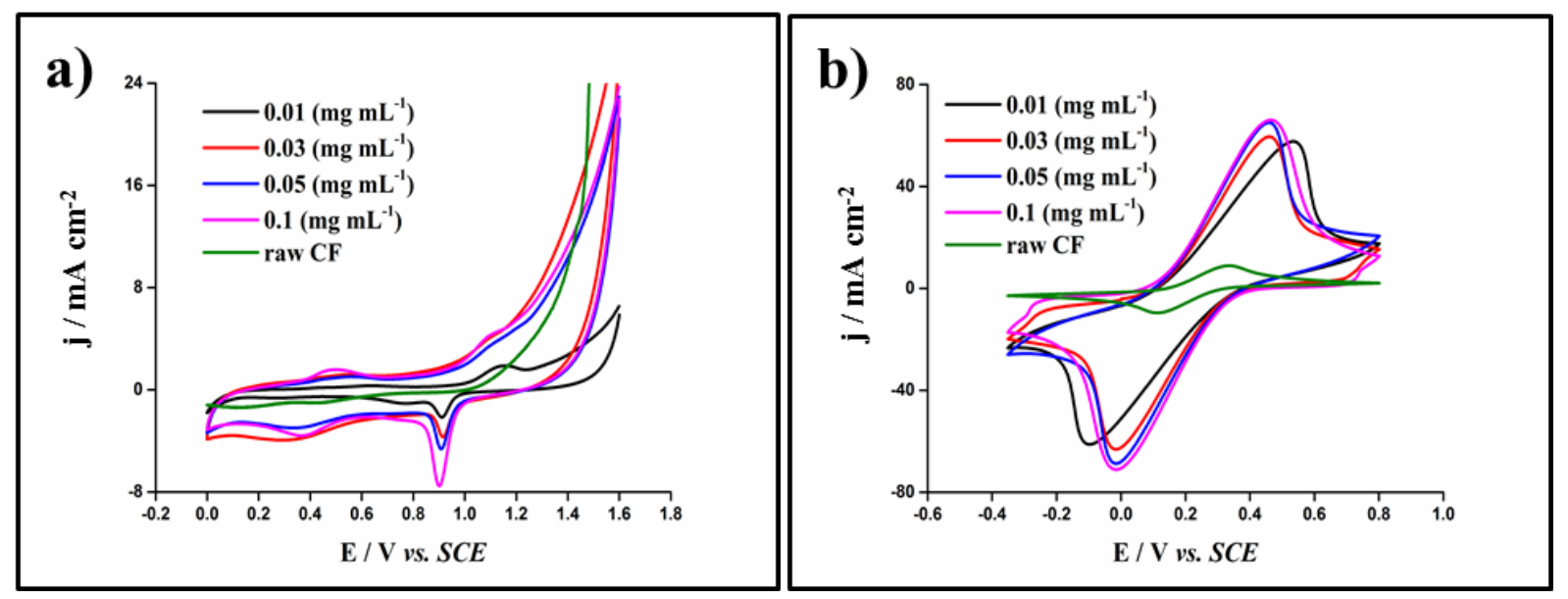

Figure 2. Cyclic voltammograms of raw $\mathrm{CF}$ and $\mathrm{Au} @ \mathrm{CF}$ electrodes (projected surface area of $1 \mathrm{~cm}^{2}$ ) at different chloroauric acid trihydrate concentrations in (a) $0.5 \mathrm{M} \mathrm{H}_{2} \mathrm{SO}_{4}$, and (b) potassium hexacyanoferrate solution (10 mM) in $1 \mathrm{M} \mathrm{KNO}_{3}$. Scan rate $10 \mathrm{mV} \mathrm{s}$.

To maximize the gold particles loading, its dependence on $\mathrm{HAuCl}_{4}$ concentration was studied. After the electrodeposition of the gold layer on the carbon felt by scanning potentials, the resulting material was characterized by $\mathrm{CVs}$ in $0.5 \mathrm{M} \mathrm{H}_{2} \mathrm{SO}_{4}$. As shown in Figure 2a, the curves present the typical peaks ascribed to the formation of Au surface oxides (around $1.1 \mathrm{~V})$ and its reduction $(0.9$ V) [36]. Increasing the concentration of $\mathrm{HAuCl}_{4}$ from 0.01 to $0.1 \mathrm{mg} \mathrm{mL}^{-1}$ in the initial solution resulted in increasing EASA of gold NPs on the Au@CF from 0.233 to $1.010 \mathrm{~cm}^{2}$ (Calculated from the theoretical charge density of gold oxide) [33].

From CVs of the redox probe potassium ferricyanide $\mathrm{Fe}(\mathrm{CN}) 6^{3-}$ (Figure $2 \mathrm{~b}$ ), the increase in $\mathrm{HAuCl}_{4}$ concentration contributes to a slight rise in the current response toward the redox waves of $\left[\mathrm{Fe}(\mathrm{CN})_{6}\right]^{3-/ 4-}$ at the gold-modified $\mathrm{CF}$, and to smaller anodic and cathodic peaks separation indicating that fast electron transfer kinetics predominantly occurred at the outermost plane of the 
NPs. The increase in gold salt concentration to $0.1 \mathrm{mg} \mathrm{mL} \mathrm{m}^{-1}$ did not lead to detectable improvement. Therefore, $0.05 \mathrm{mg} \mathrm{mL}^{-1}$ of chloroauric acid trihydrate was chosen as optimal concentration for the electrodeposition step.

\subsection{Effect of the heating temperature}
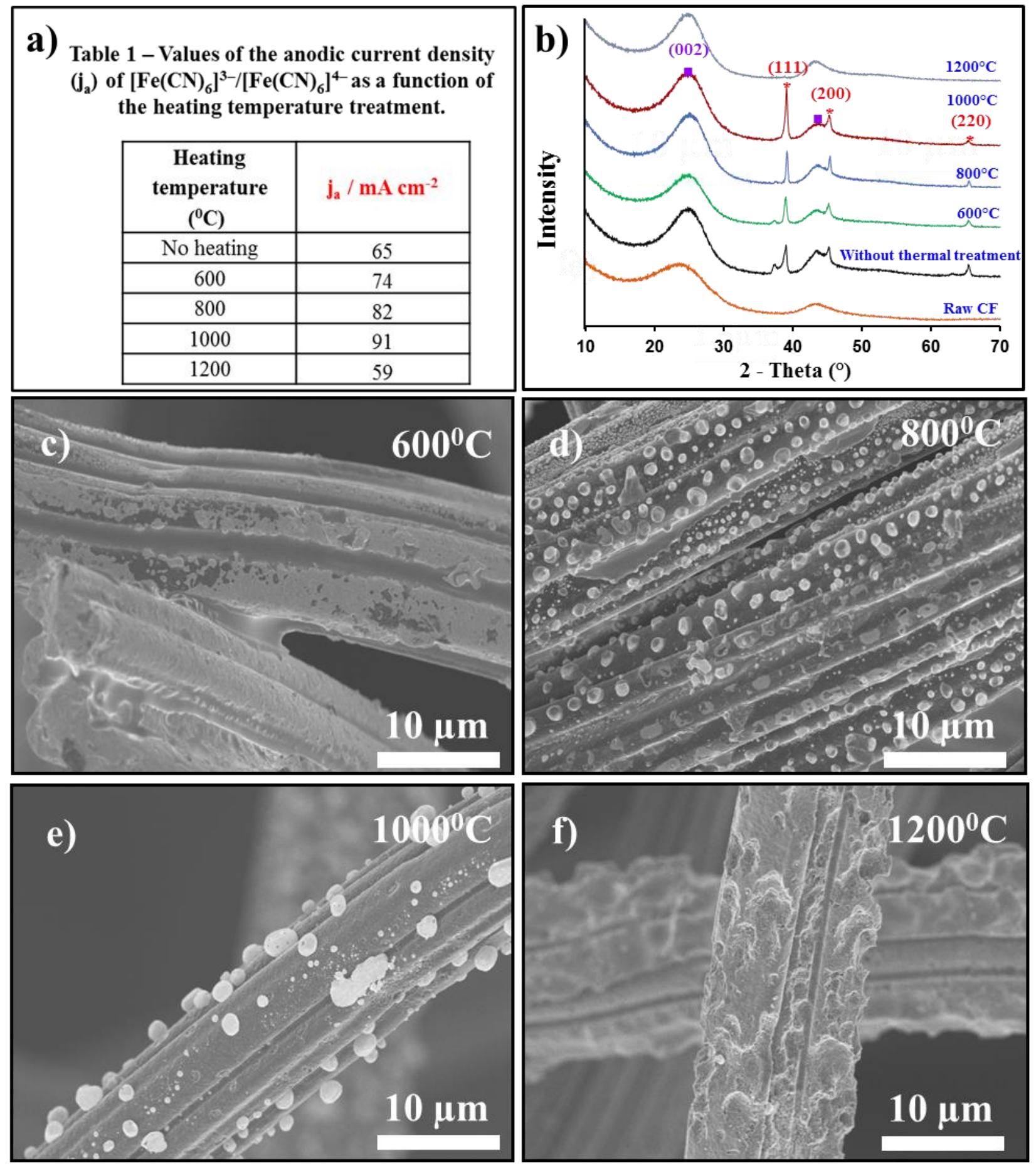

Figure 3. (a) Table 1 - Values of the anodic current density $\left(\mathrm{j}_{\mathrm{a}}\right)$ of $\left[\mathrm{Fe}(\mathrm{CN})_{6}\right]^{3-} /\left[\mathrm{Fe}(\mathrm{CN})_{6}\right]^{4-}$ as a function of the heating temperature treatment. (b) X-ray diffraction patterns of $\mathrm{Au} @ \mathrm{CF}\left(0.05 \mathrm{mg} \mathrm{mL} \mathrm{HAuCl}_{4} \mathrm{H}^{-1} \mathrm{H}_{2} \mathrm{O}\right)$ electrodes at different 
treatment temperatures: Au $\left(^{*}\right)$, carbon (-). SEM images of $\mathrm{Au} @ \mathrm{CF}\left(0.05 \mathrm{mg} \mathrm{mL}^{-1} \mathrm{HAuCl}_{4} .3 \mathrm{H}_{2} \mathrm{O}\right)$ electrodes at different treatment temperatures: (c) $600{ }^{\circ} \mathrm{C}$, (d) $800{ }^{\circ} \mathrm{C}$, (e) $1000{ }^{\circ} \mathrm{C}$, (f) $1200{ }^{\circ} \mathrm{C}$.

The thermal treatment plays an important role in the transformation of the gold layer to gold particles and in the elimination of contaminants. Consequently, the electrochemical behavior of the modified electrodes changes with the applied temperature treatment when the temperature rises from 600 to $1000{ }^{\circ} \mathrm{C}$, as shown by the continuous increase in the anodic peak $\mathrm{j}_{\mathrm{a}}$ of $\left[\mathrm{Fe}(\mathrm{CN})_{6}\right]^{3-4-}$ at the $\mathrm{Au} @ \mathrm{CF}$ electrodes (Figure 3a), determined from the CVs of $\mathrm{Fe}(\mathrm{CN})_{6}{ }^{3-}$ in PBS at scan rate $10 \mathrm{mV} \mathrm{s}^{-1}$. Higher temperature is not beneficial, as will be explained later.

In order to understand the NPs growth with heating treatment, Au@CF was characterized by $\mathrm{XRD}$, as shown in Figure 3b. In the absence of thermal treatment, a small peak around $37^{\circ}$ is assigned to complexes between $\mathrm{Au}$ and $\mathrm{Cl}$ coming from the uncompleted reduction of chloroauric acid by $\mathrm{CV}$ method. This peak disappears by heating at higher temperature. The thermal treatment involves multiple and competitive mechanisms for the formation of gold particles: first, at low temperature $\left(<600^{\circ} \mathrm{C}\right)$ dewetting related to different expansion coefficients between the gold and the carbon felt support $[37,38]$ induce the formation of the first Au droplets (Figure 3c). This step is followed by the coalescence of the gold particles to form larger particles in order to reduce the total interfacial energy of the system. Gold particles tend to aggregate through coalescence [39]. Thus, gold is seen in the form of a rugged layer of Au droplets covering the surface of carbon fibers (Figure 3d).

At higher temperature (more than $600{ }^{\circ} \mathrm{C}$ ), the Ostwald ripening process occurred by diffusion of the atoms (via evaporation or surface diffusion) from one particle to another [40] [30] to form the hexagon-shaped gold particles with an average size of $300 \mathrm{~nm}$ (Figure 3e). At this temperature the XRD peak $\mathrm{Au}(111)$ at $38.2^{\circ}$ is increased relying on the crystallization of Au during the heat treatment $[34,39]$. However, applying too high annealing temperature of $1200^{\circ} \mathrm{C}$ leads to a decrease of the anodic current density of the redox wave $\left[\mathrm{Fe}(\mathrm{CN})_{6}\right]^{3-} /\left[\mathrm{Fe}(\mathrm{CN})_{6}\right]^{4-}$ (Figure 3a). This comes from the fact that at this temperature gold nanoparticles are evaporated. No more peaks of 
$\mathrm{Au}$ are observed on the XRD diffraction (Figure 3b) and a rough surface without gold on SEM image (Figure 3f) is noticed. This indicates that the selection of the appropriate treatment temperature is crucial for the formation of gold nanoparticles on carbon felt.

\subsection{Au@CF as support for electrocatalysis}

\subsubsection{Enzymatic $\mathrm{O}_{2}$ reduction on $\mathrm{CF} @ \mathrm{Au}$}
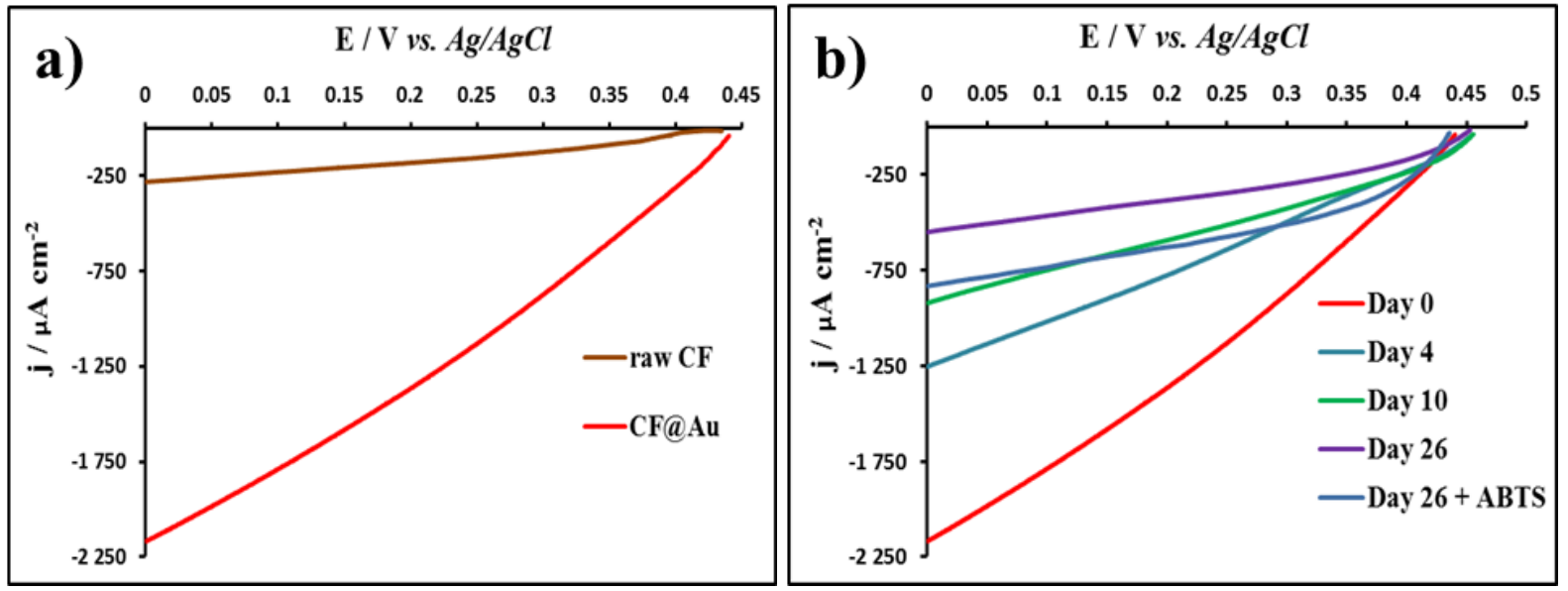

Figure 4. (a) Polarization curves of $\mathrm{O}_{2}$ electroreduction on the $\mathrm{Au} @ \mathrm{CF}$ and the raw $\mathrm{CF}$ biocathodes modified with the enzyme BOD. (b) Stability of the BOD-immobilized Au@CF electrode with time. Scan rate of $3 \mathrm{mV} \mathrm{s}^{-1}, \mathrm{O}_{2}$-saturated PBS 0.1 M, pH 7.0 at $30{ }^{\circ} \mathrm{C}$.

The electrochemical response of the BOD-immobilized Au@CF electrode is shown in Figure 4a, compared to a control biocathode prepared by the same immobilization technique on a raw $\mathrm{CF}$ electrode. The polarization curves were performed in oxygen saturated PBS pH 7.0. The oxygen reduction current begins at around $0.45 \mathrm{~V}$ ( $\mathrm{vs} \mathrm{Ag} / \mathrm{AgCl})$, which is in good agreement with the reported values in the literature for the T1 site of BOD from Myrothecium verrucaria [16]. No catalytic current was observed in nitrogen saturated solution. The delivered current shows an almost linear potential dependence and the absence of a semi-plateau. This phenomenon was also observed for non-mediated system with porous structure like carbonaceous foams [41] and carbon aerogel [42]. In such 3-dimensional materials, the enzymes are randomly oriented on the support, which induces a wide distribution in interfacial electron transfer rates and thus larger overpotentials to electrically connect all the enzymes. 
The Au@CF biocathode shows the highest performance $2.160 \mathrm{~mA} \mathrm{~cm}^{-2}$ at $0 \mathrm{~V}$ (vs $\mathrm{Ag} / \mathrm{AgCl}$ ), which corresponds to an increase by 8 -folds compared to the raw electrode. This outstanding performance comes from the presence of the gold particles that enhance the electronic conductivity of the electrode and the surface area. The stability of the electrode was investigated periodically (Figure 4b) and between each testing time, the electrode was stored at $5{ }^{\circ} \mathrm{C}$ in a humid environment. For a 26 day-period, a significant reducing activity of the biocathode (-75\%) was observed, explained by several reasons such as enzyme inactivation, loss of electrical connection and desorption. The addition of $3 \mathrm{mM}$ of ABTS in the solution at the $26^{\text {th }}$ day (Figure $4 \mathrm{~b}$ ) gives rise to a noticeable increase in the current density, indicating that some enzymes have kept their activity but are no longer properly electrically connected to the electrode surface.

\subsubsection{Glucose electrooxidation on $\mathrm{CF} @ \mathrm{Au}$}

In the following studies, the most promising $\mathrm{Au} @ \mathrm{CF}$ electrode obtained from the $0.05 \mathrm{mg} \mathrm{mL} \mathrm{m}^{-1}$ concentration of chloroauric acid trihydrate and the thermal treatment at $1000{ }^{\circ} \mathrm{C}$ under nitrogen was employed. This electrode was applied to glucose electrooxidation at basic $\mathrm{pH}$, since at neutral $\mathrm{pH}$ the electroactivity of the $\mathrm{Au} @ \mathrm{CF}$ is lowered toward glucose oxidation (see Figure S3). For that reason, the performance of the hybrid device was tested in a compartmentalized system at two different $\mathrm{pH}$ values.
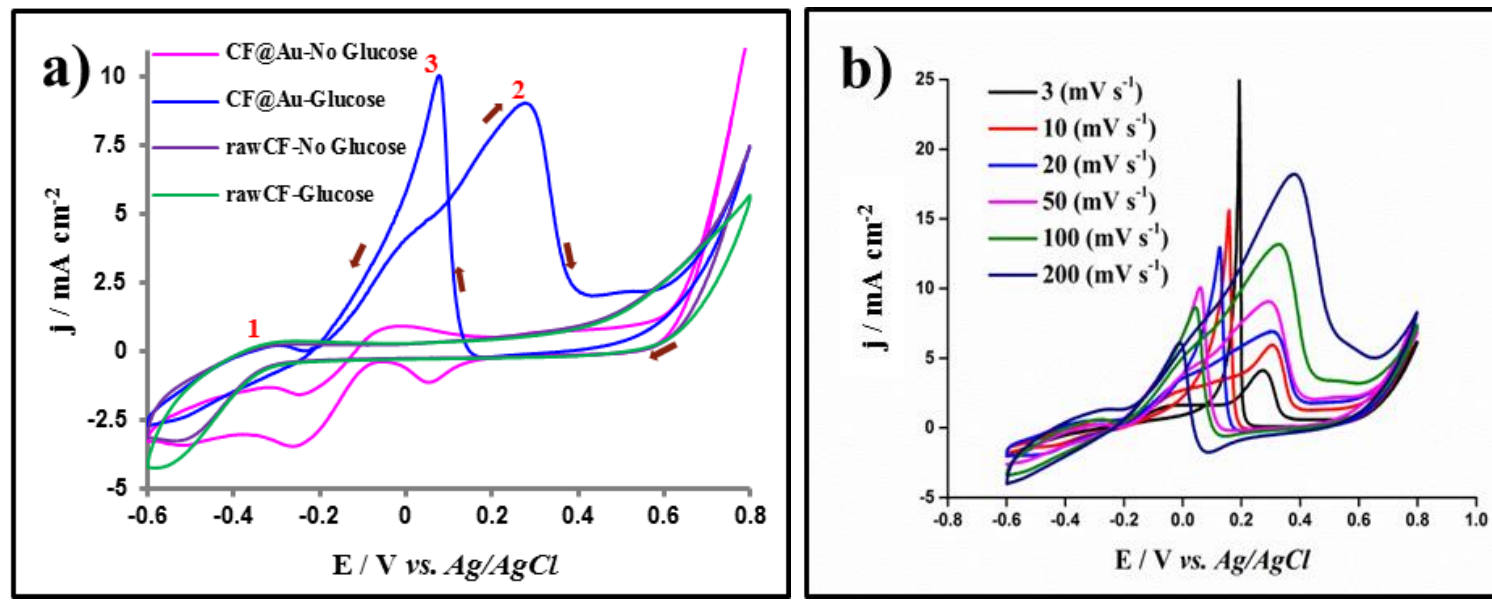

Figure 5. Cyclic voltammograms in $10 \mathrm{mM}$ glucose in $0.1 \mathrm{M} \mathrm{KOH}$ of (a) Au@CF and raw CF anodes in the presence and absence of $10 \mathrm{mM}$ glucose at $50 \mathrm{mV} \mathrm{s}^{-1}$, and of (b) Au@CF anode at various scan rates. 
The direct electro-oxidation of glucose was monitored by running cyclic voltammograms in $0.1 \mathrm{M} \mathrm{KOH}$ solution in the presence and absence of glucose $10 \mathrm{mM}$ on $\mathrm{Au} @ \mathrm{CF}$ and raw $\mathrm{CF}$ electrodes for comparison. In the absence of glucose (Figure 5a), the CV of the Au@CF electrode exhibits the two small electrochemical processes relative to gold surface oxides formation and reduction, respectively, in alkaline media $[43,44]$. In the presence of glucose, raw CF is not active for glucose electrooxidation in the potential range investigated, whereas, the $\mathrm{Au} @ \mathrm{CF}$ electrode shows the typical voltammetric behavior characterized by three electrochemical processes: (1) formation of an adsorbed glucose layer on the gold electrode surface through the dehydrogenation of anomeric carbon of glucose molecules [45, 46], (2) oxidation of the previously adsorbed glucose intermediates to gluconolactone species, leading to the appearance of a large left shoulder pick arround $0.3 \mathrm{~V}$, and (3) re-adsorption and oxidation of glucose [47]. Figure $5 \mathrm{~b}$ shows that the positions of the peaks are dislocated when varying the scan rate, which is a point to consider when comparing different works. Compared to the literature on glucose oxidation by materials decorated with gold nanoparticles [48-51], the Au@CF delivered very competitive values with a peak intensity around $9 \mathrm{~mA} \mathrm{~cm}$-2 for the glucose oxidation to gluconolactone species, although comparison depends on the preparation methods, amount and form of active gold NPs on the electrodes. As recently mentioned by a recent work of $\mathrm{K}$. Boniface and co-workers [52], it is noteworthy to determine the regime of glucose electrooxidation reaction on the CF@Au. From Figure 5b, for the peak " 2 ", it was deduced the plots of $\log \left(j_{p}\right)$ as a function of $\log (v)$ (Figure $\left.S 4\right)$. The slope is lower than 0.5, suggesting that the electrooxidation of glucose on the CF@Au has a complex mechanism involving additional phenomena than diffusion and adsorption. This behavior was also observed for spherical gold nanoparticles [52] and for polycrystalline gold electrodes $[53]$.

\subsection{Glucose $/ \mathrm{O}_{2}$ hybrid biofuel cell}



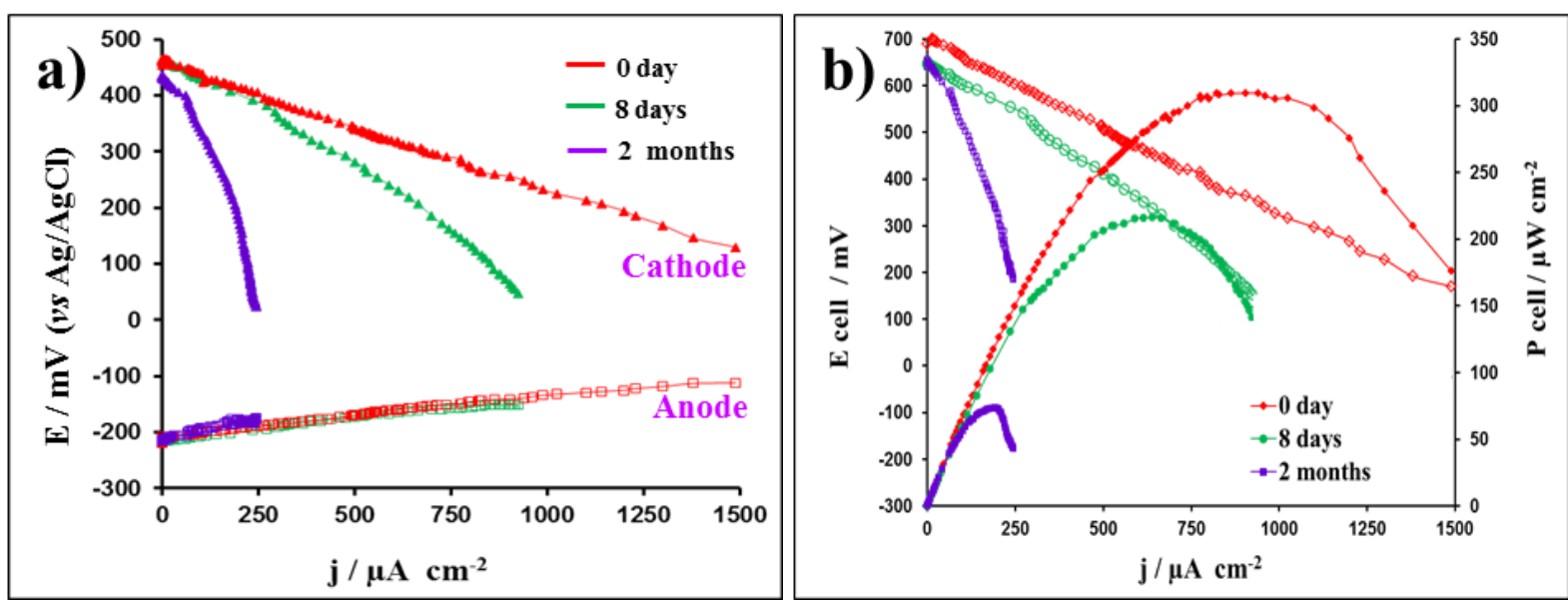

Figure 6. Electrical performance of the hybrid biofuel cell at $30{ }^{\circ} \mathrm{C}$ with BOD-immobilized $\mathrm{Au} @ \mathrm{CF}$ cathode in $\mathrm{O}_{2^{-}}$ saturated PBS $(0.1 \mathrm{M}, \mathrm{pH}=7.0)$ and $\mathrm{Au} @ \mathrm{CF}$ anode in $0.1 \mathrm{M} \mathrm{KOH}(\mathrm{pH}=11.0)$ containing $10 \mathrm{mM}$ glucose. a) Monitoring of the potentials $\mathrm{E}_{\text {anode }}$ and $\mathrm{E}_{\text {cathode }}$ with an $\mathrm{Ag} / \mathrm{AgCl}$ reference electrode immersed in each compartment, ( $\Delta) \mathrm{E}_{\text {cathode, }}(\square) \mathrm{E}_{\text {anode. }}$ b) Profile of the delivered $\mathrm{E}_{\text {cell }}$ potentials and power density of the hybrid biofuel cell recorded from day 0 until 2 months. The biocathode was stored at $5{ }^{\circ} \mathrm{C}$ between each test.

A complete hybrid glucose $/ \mathrm{O}_{2} \mathrm{BFC}$ was implemented by connecting the abiotic anode and the biocathode based on Au@CF in a two-chamber cell separated by a Nafion ${ }^{\circledR}$ membrane. Steadystate measurements were performed by applying various external resistances (ERs) values. The evolution of the potential of each electrode was measured independently by introducing a reference electrode $(\mathrm{Ag} / \mathrm{AgCl})$ in each compartment (Fig 6a). The output potential and current of the hybrid biofuel cell were read on multimeter devices at the same time (Fig. 6b). The hybrid biofuel cell delivered an open circuit voltage (OCV) of 0.707 V. Figure 6a displays the anodic and cathodic polarization curves. The anode potential starts at $-220 \mathrm{mV}$ and varies to $-112 \mathrm{mV} v \mathrm{~s}$ $\mathrm{Ag} / \mathrm{AgCl}$, corresponding to $\Delta \mathrm{E}_{\text {anode }}=108 \mathrm{mV}$. On the contrary, the variation of the cathode potential is more important, from $461 \mathrm{mV}$ to $130 \mathrm{mV} v s \mathrm{Ag} / \mathrm{AgCl}$, meaning $\Delta \mathrm{E}_{\text {cathode }}=331 \mathrm{mV}$. The long-term stability of the electrodes was studied by recording the polarization curves after one week and after 2 months. As observed in Figure 6a, the stability of the cathode decreases with time, as already observed in Figure $4 \mathrm{~b}$. The cell performance was thus limited by the cathodic reaction, which performance relied on the enzyme stability and electrical connection. This result points out the well-established stability of abiotic materials as anode for glucose electrooxidation to construct hybrid devices. In Figure 6b, the typical power profile of the hybrid device shows a 
maximum power density of $310 \mu \mathrm{W} \mathrm{cm}{ }^{-2}$ at $352 \mathrm{mV}$. The performance was significantly enhanced compared to our previous devices fabricated from carbon electrospun fibers: $35 \mu \mathrm{W} \mathrm{cm}{ }^{-2}$ with gold loading $20 \%$ [25] and $65 \mu \mathrm{W} \mathrm{cm}{ }^{-2}$ with gold loading $22 \%$ [26]. Considering that our carbon felt electrodes were highly porous, it appeared more reasonable to relate the power to the electrode volume immersed in the solutions instead of the projected surface area. By considering the thickness $1 \mathrm{~cm}$ of the electrodes, the maximum volumic power was $310 \mu \mathrm{W} \mathrm{cm}{ }^{-3}$. Additionaly, it was observed that the volumic power was similar for different thicknesses between 0.5 and $3 \mathrm{~cm}$, suggesting homogeneous impregnation of the species through the whole thickness of the electrodes.

The quality of these first results gives rise to several perspectives for further enhancements in the system as a whole, like the withdrawal of the separating membrane, or works on the enzyme/gold connection. So far, the major benefit of the developed Au@CF consists in the fact it is a free-standing material with increased reactive surface area, induced by the Au particles presence per projected surface area. Au@CF material is therefore able to contain high enzyme loadings, and presents high diffusion transport thanks to the porous carbon template.

\section{Conclusions}

A synthetic route of a gold particles-modified felt was performed by electrodeposition of gold salts on a porous carbon template followed by a subsequent thermal treatment at $1000{ }^{\circ} \mathrm{C}$. This method allowed for the dewetting of Au covering the surface of the carbon felt to form hexagonshaped gold particles homogeneously distributed with an average size of $300 \mathrm{~nm}$. The presence of the Au particles enhanced the electroactivityof the Au@CF compared to the raw CFs. A complete hybrid glucose $/ \mathrm{O}_{2}$ BFC was implemented by connecting the abiotic anode and the biocathode based on Au@CF. The BFC exhibited higher electrochemical performance than other reported hybrid glucose biofuel cells, despite a low gold loading $(0.2 \mathrm{wt} \%)$. It proved the efficient electrochemical activity of the Au@CF toward glucose oxidation in alkaline medium and toward enzymatic dioxygen electroreduction by the enzyme BOD in neutral $\mathrm{pH}$. Perspectives for this 
work include the removal of the BFC separating membrane, which could simplify the device. This might be achieved after further research on the limitations of the abiotic anode, for instance.

\section{Acknowledgment}

We gratefully acknowledge financial support from Vietnamese government (VIED- Vietnam International Education Development - Project 911).

\section{References}

[1] E. Seker, M.L. Reed, M.R. Begley, Nanoporous Gold: Fabrication, Characterization, and Applications, Materials, 2 (2009) 2188-2215.

[2] J. Erlebacher, An Atomistic Description of Dealloying Porosity Evolution, the Critical Potential, and RateLimiting Behavior, J. Electrochem. Soc., 151 (2004) C614-C626.

[3] S. Aquino Neto, T.S. Almeida, L.M. Palma, S.D. Minteer, A.R. de Andrade, Hybrid nanocatalysts containing enzymes and metallic nanoparticles for ethanol/O2 biofuel cell, Journal of Power Sources, 259 (2014) 25-32.

[4] K. Murata, K. Kajiya, N. Nakamura, H. Ohno, Direct electrochemistry of bilirubin oxidase on threedimensional gold nanoparticle electrodes and its application in a biofuel cell, Energy \& Environmental Science, 2 (2009) 1280.

[5] V. Andoralov, M. Falk, D.B. Suyatin, M. Granmo, J. Sotres, R. Ludwig, V.O. Popov, J. Schouenborg, Z. Blum, S. Shleev, Biofuel cell based on microscale nanostructured electrodes with inductive coupling to rat brain neurons, Sci Rep, 3 (2013) 3270.

[6] F.N. Crespilho, M. Emilia Ghica, M. Florescu, F.C. Nart, O.N. Oliveira, C.M.A. Brett, A strategy for enzyme immobilization on layer-by-layer dendrimer-gold nanoparticle electrocatalytic membrane incorporating redox mediator, Electrochemistry Communications, 8 (2006) 1665-1670.

[7] A. Karczmarczyk, A. Celebanska, W. Nogala, V. Sashuk, O. Chernyaeva, M. Opallo, Electrocatalytic glucose oxidation at gold and gold-carbon nanoparticulate film prepared from oppositely charged nanoparticles, Electrochimica Acta, 117 (2014) 211-216.

[8] L. Wang, E. Wang, Direct electron transfer between cytochrome $\mathrm{c}$ and a gold nanoparticles modified electrode, Electrochemistry Communications, 6 (2004) 49-54.

[9] Q. Kang, L. Yang, Q. Cai, An electro-catalytic biosensor fabricated with Pt-Au nanoparticle-decorated titania nanotube array, Bioelectrochemistry, 74 (2008) 62-65.

[10] V.G. Praig, G. Piret, M. Manesse, X. Castel, R. Boukherroub, S. Szunerits, Seed-mediated electrochemical growth of gold nanostructures on indium tin oxide thin films, Electrochimica Acta, 53 (2008) 7838-7844.

[11] M.D. Scanlon, U. Salaj-Kosla, S. Belochapkine, D. MacAodha, D. Leech, Y. Ding, E. Magner, Characterization of nanoporous gold electrodes for bioelectrochemical applications, Langmuir, 28 (2012) 2251-2261.

[12] S. Tuncagil, C. Ozdemir, D.O. Demirkol, S. Timur, L. Toppare, Gold nanoparticle modified conducting polymer of 4-(2,5-di(thiophen-2-yl)-1H-pyrrole-1-I) benzenamine for potential use as a biosensing material, Food Chem, 127 (2011) 1317-1322.

[13] Y. Fu, F. Liang, H. Tian, J. Hu, Nonenzymatic glucose sensor based on ITO electrode modified with gold nanoparticles by ion implantation, Electrochimica Acta, 120 (2014) 314-318.

[14] W. Putzbach, N.J. Ronkainen, Immobilization techniques in the fabrication of nanomaterial-based electrochemical biosensors: a review, Sensors (Basel), 13 (2013) 4811-4840.

[15] K. Murata, K. Kajiya, M. Nukaga, Y. Suga, T. Watanabe, N. Nakamura, H. Ohno, A Simple Fabrication Method for Three-Dimensional Gold Nanoparticle Electrodes and Their Application to the Study of the Direct Electrochemistry of Cytochromec, Electroanalysis, 22 (2010) 185-190. 
[16] U. Salaj-Kosla, S. Pöller, Y. Beyl, M.D. Scanlon, S. Beloshapkin, S. Shleev, W. Schuhmann, E. Magner, Direct electron transfer of bilirubin oxidase (Myrothecium verrucaria) at an unmodified nanoporous gold biocathode, Electrochemistry Communications, 16 (2012) 92-95.

[17] M. Tominaga, T. Shimazoe, M. Nagashima, I. Taniguchi, Electrocatalytic oxidation of glucose at gold nanoparticle-modified carbon electrodes in alkaline and neutral solutions, Electrochemistry Communications, 7 (2005) 189-193.

[18] M. Falk, V. Andoralov, Z. Blum, J. Sotres, D.B. Suyatin, T. Ruzgas, T. Arnebrant, S. Shleev, Biofuel cell as a power source for electronic contact lenses, Biosens Bioelectron, 37 (2012) 38-45.

[19] S. Aquino Neto, R.D. Milton, L.B. Crepaldi, D.P. Hickey, A.R. de Andrade, S.D. Minteer, Coimmobilization of gold nanoparticles with glucose oxidase to improve bioelectrocatalytic glucose oxidation, Journal of Power Sources, 285 (2015) 493-498.

[20] S. Boland, D. Leech, A glucose/oxygen enzymatic fuel cell based on redox polymer and enzyme immobilisation at highly-ordered macroporous gold electrodes, Analyst, 137 (2012) 113-117.

[21] X. Wang, M. Falk, R. Ortiz, H. Matsumura, J. Bobacka, R. Ludwig, M. Bergelin, L. Gorton, S. Shleev, Mediatorless sugar/oxygen enzymatic fuel cells based on gold nanoparticle-modified electrodes, Biosens Bioelectron, 31 (2012) 219-225.

[22] Jianbo Jia, Bingquan Wang, G.C. Aiguo Wu, Zhuang Li, S. Dong, A Method to Construct a ThirdGeneration Horseradish Peroxidase Biosensor Self-Assembling Gold Nanoparticles to Three-Dimensional Sol-Gel Network, Anal Chem, 74 (2002) 2217-2223.

[23] V. Matveeva, A. Bykov, V. Doluda, M. Sulman, N. Kumar, S. Dzwigaj, E. Marceau, L. Kustov, O. Tkachenko, E. Sulman, Direct d-Glucose Oxidation over Noble Metal Nanoparticles Introduced on Polymer and Inorganic Supports, Topics in Catalysis, 52 (2009) 387-393.

[24] M. Pasta, R. Ruffo, E. Falletta, C. M. Mari, C.D. Pina, Alkaline glucose oxidation on nanostructured gold electrodes, Gold Bull, 43 (2010) 57-64.

[25] Matthew T. Meredith, Der-You Kao, David Hickey, David W. Schmidtke, D.T. Glatzhofer, High Current Density Ferrocene-Modified Linear Poly(ethylenimine) Bioanodes and Their Use in Biofuel Cells, Electrochem. Soc. , 158 (2011) B166-B174.

[26] Nicolas Mano, Fei Mao, A. Heller, Characteristics of a Miniature Compartment-less Glucose-O2 Biofuel Cell and Its Operation in a Living Plant, JACS, 125 (2003) 6588-6594.

[27] Minling Shao, Muhammad Nadeem Zafar, Magnus Falk, Roland Ludwig, Christoph Sygmund, Clemens K. Peterbauer, Dmitrii A. Guschin, Domhnall MacAodha, Peter Ó Conghaile, Dónal Leech, Miguel D. Toscano, Sergey Shleev, Wolfgang Schuhmann, Lo Gorton, Optimization of a Membraneless Glucose/Oxygen Enzymatic Fuel Cell Based on a Bioanode with High Coulombic Efficiency and Current Density, ChemPhysChem, 14 (2013) 2260-2269.

[28] Y. Holade, A. Both Engel, S. Tingry, A. Cherifi, D. Cornu, K. Servat, T.W. Napporn, K.B. Kokoh, Insights on Hybrid Glucose Biofuel Cells Based on Bilirubin Oxidase Cathode and Gold-Based Anode Nanomaterials, ChemElectroChem, 1 (2014) 1976-1987.

[29] A. Both Engel, M. Bechelany, O. Fontaine, A. Cherifi, D. Cornu, S. Tingry, One-Pot Route to Gold Nanoparticles Embedded in Electrospun Carbon Fibers as an Efficient Catalyst Material for Hybrid Alkaline Glucose Biofuel Cells, ChemElectrochem, 3 (2016) 629-637

[30] M. Bechelany, X. Maeder, J. Riesterer, J. Hankache, D. Lerose, S. Christiansen, J. Michler, L. Philippe, Synthesis Mechanisms of Organized Gold Nanoparticles: Influence of Annealing Temperature and Atmosphere, Crystal Growth \& Design, 10 (2010) 587-596.

[31] Scott Calabrese Barton, Josh Gallaway, P. Atanassov, Enzymatic Biofuel Cells for Implantable and Microscale Devices, Chemical Reviews, 104 (2004) 4867-4886.

[32] S. El Ichi, A. Zebda, J.-P. Alcaraz, A. Laaroussi, F. Boucher, J. Boutonnat, N. Reverdy-Bruas, D. Chaussy, M. N. Belgacem, P. Cinquin, D.K. Martin, Bioelectrodes modified with chitosan for long-term energy supply from the body, Energy \& Environmental Science, 8 (2015) 1017.

[33] Trasatti S., P. O., REAL SURFACE AREA MEASUREMENTS IN ELECTROCHEMISTRY Pure Applied Chemistry 63 (1991) 711-734.

[34] WEIMIN HUANG, J. SHI, Synthesis and Properties of ZrO2 Films Dispersed With Au Nanoparticles, Journal of Sol-Gel Science and Technology, 20 (2001) 145-151. 
[35] R.P. Ramasamy, S.M. Maliyekkal, Formation of gold nanoparticles upon chitosan leading to formation and collapse of gels, New J. Chem., 38 (2014) 63-69.

[36] Bikash Kumar Jena, Stephen J. Percival, B. Zhang, Au Disk Nanoelectrode by Electrochemical Deposition in a Nanopore, Analytical Chemistry, 82 ( 2010) 6737-6743.

[37] C.M. Muller, F.C. Mornaghini, R. Spolenak, Ordered arrays of faceted gold nanoparticles obtained by dewetting and nanosphere lithography, Nanotechnology, 19 (2008) 485306.

[38] S. Namsani, J.K. Singh, Dewetting dynamics of a gold film on graphene: implications for nanoparticle formation, Faraday Discuss, 186 (2016) 153-170.

[39] M.I. Ali Umar, C.C. Yap, R. Awang, A. Ali Umar, M. Mat Salleh, M. Yahaya, Formation of gold-coated multilayer graphene via thermal reduction, Materials Letters, 106 (2013) 200-203.

[40] R.S. Goeke, A.K. Datye, Model oxide supports for studies of catalyst sintering at elevated temperatures, Topics in Catalysis, 46 (2007) 3-9.

[41] V. Flexer, N. Brun, O. Courjean, R. Backov, N. Mano, Porous mediator-free enzyme carbonaceous electrodes obtained through Integrative Chemistry for biofuel cells, Energy Environ. Sci., 4 (2011) 20972106.

[42] S. Tsujimura, Y. Kamitaka, K. Kano, Diffusion-Controlled Oxygen Reduction on Multi-Copper OxidaseAdsorbed Carbon Aerogel Electrodes without Mediator, Fuel Cells, 7 (2007) 463-469.

[43] S.B. Aoun, Electrocatalytic Oxidation of Glucose at Gold Nanoparticle-modified PFC electrodes in an Alkaline Solution, Journal of Materials and Environmental Science, 4 (2013) 887-892.

[44] M. Pasta, F. La Mantia, Y. Cui, Mechanism of glucose electrochemical oxidation on gold surface, Electrochimica Acta, 55 (2010) 5561-5568.

[45] C. Paul Wilde, M. Zhang, Oxidation of Glucose at Electrodeposited Platinum Electrodes in Alkaline Solution Journal of the Chemical Society, Faraday Transactions 1, 89 (1993) 385-389.

[46] Xiuling Yan, Xingbo Ge, S. Cui, Pt-decorated nanoporous gold for glucose electrooxidation in neutral and alkaline solutions, Nanoscale Research Letters, 6 (2011) 313.

[47] R.R. M. Pasta, E.Falletta, C.M. Mari, C.D. Pina, Alkaline glucose oxidation on nanostructured gold electrodes, Gold Bulletin, 43 (2010) 57-64.

[48] J. Zhao, X. Kong, W. Shi, M. Shao, J. Han, M. Wei, D.G. Evans, X. Duan, Self-assembly of layered double hydroxide nanosheets/Au nanoparticles ultrathin films for enzyme-free electrocatalysis of glucose, Journal of Materials Chemistry, 21 (2011) 13926.

[49] Sze-Ping Tung, Ting-Kai Huang, C.-Y. Lee, H.-T. Chiu, Electrochemical growth of gold nanostructures on carbon paper for alkaline direct glucose fuel cell, RSC Advances, 2 (2012) 1068-1073.

[50] C. Zhu, S. Guo, S. Dong, PdM (M = Pt, Au) bimetallic alloy nanowires with enhanced electrocatalytic activity for electro-oxidation of small molecules, Adv Mater, 24 (2012) 2326-2331.

[51] S. Biella, M. Rossi, Gas phase oxidation of alcohols to aldehydes or ketones catalysed by supported gold, Chemical Communications, (2003) 378-379.

[52] S. Hebié, T. W. Napporn, C. Morais, B. Kokoh, Size-Dependent Electrocatalytic Activity of Free Gold Nanoparticles for the Glucose Oxidation Reaction, ChemPhysChem, 17 (2016) 1454-1462.

[53] L.H.Essis Yei, B. Beden, C. Lamy, Electrocatalytic oxidation of glucose at platinum in alkaline medium: on the role of temperature, J. Electroanal. Chem., 246 (1988) 349-362. 